\title{
Notes on the spider genus Bisetifer Tanasevitch, 1987 (Aranei: Linyphiidae), with the description of a new species
}

\section{О пауках рода Bisetifer Tanasevitch, 1987 (Aranei: Linyphiidae) с описанием нового вида}

\author{
A.V. Tanasevitch ${ }^{1}$, A.V. Ponomarev ${ }^{2}$, Yu.A. Chumachenko ${ }^{3}$ \\ А.В. Танасевич ${ }^{1}$, А.В. Пономарев ${ }^{2}$ Ю.А. Чумаченко ${ }^{3}$

\begin{abstract}
${ }^{1}$ Institute of Ecology and Evolution, Russian Academy of Sciences, Leninsky prospect, 33, Moscow 119071, Russia. E-mail: tanasevitch@gmail.com

Институт проблем экологии и эволюции РАН, Ленинский проспект, 33, Москва 119071, Россия.

${ }^{2}$ Institute of Arid Zones, Southern Scientific Centre, Russian Academy of Sciences, Chekhov str., 41, Rostov-on-Don 344006, Russia. Email: ponomarev1952@mail.ru

Институт аридных зон, Южный научный центр РАН, пр. Чехова, 41, Ростов-на-Дону 344006, Россия.

${ }^{3}$ Caucasian State Biosphere Nature Reserve, Sovetskaya av., 187, Maykop 385000 Russia. E-mail: ychumachenko73@mail.ru

Кавказский государственный природный биосферный заповедник, ул. Советская, 187, Майкоп 385000, Россия.
\end{abstract}

KEY WORDS: Dwarf-spiders, Erigoninae, Caucasus, Russia, Georgia, Azerbaijan, new species.

КЛЮЧЕВЫЕ СЛОВА: Пауки-пигмеи, Erigoninae, Кавказ, Россия, Грузия, Азербайджан, новый вид.

ABSTRACT: Revision of the type series of Bisetifer cephalotus Tanasevitch, 1987, shows this species to be heterogeneous and, besides the nominate form, the series to contain another, very similar, new species, $B$. gruzin sp.n. The female, originally described as corresponding to the male of $B$. cephalotus, is actually the female of the new species. The true female of $B$. cephalotus is described for the first time. Fresh samples from the Krasnodar Province, southern Russia and from Georgia show that B. gruzin sp.n. seems to be much more widely distributed in the Caucasus than $B$. cephalotus.

РЕЗЮМЕ: Типовая серия Bisetifer cephalotus Tanasevitch, 1987, помимо номинального вида, coдержит еще один близкий к нему вид, B. gruzin sp.n. Самка, первоначально описанная как пара к самцу B. cephalotus, в действительности относится к новому виду. Самка B. cephalotus описана впервые. Недавние сборы с Кавказа показали, что B. gruzin sp.n. распространен здесь значительно шире, чем B. cephalotus.

\section{Introduction}

The hitherto monotypic genus Bisetifer Tanasevitch, 1987, was described from the Krasnodar Province, Russia and from Georgia, Caucasus, with B. cephalotus Tanasevitch, 1987, as type-species [Tanasevitch, 1987]. This species has since been recorded (as it appears, mainly erroneously) from numerous localities in Georgia, Azerbaijan [Tanasevitch, 1990], Krasnodar Prov- ince [Ponomarev, Chumachenko, 2007], as well as the Crimea [Kovblyuk, 2007].

A new material recently collected in the Caucasus has prompted us to revise all earlier samples, including type specimens. Revision of the type series of B. cephalotus shows the taxon to be heterogeneous and, besides the nominate species, the series to contain another, very closely related, new species. Secondly, the female, originally described as corresponding to the male of $B$. cephalotus, appears to be conspecific with the new species.

Descriptions of both the new species of Bisetifer and of the true female of $B$. cephalotus, following a reexamination of the type and other comparative material of $B$. cephalotus, are the subject of the present paper.

\section{Material and methods}

This paper is based on a study of the type and other comparative material kept both at the Zoological Museum of the Moscow State University, Moscow, Russia (ZMMU) and in the personal collection of Andrei Tanasevitch (CAT). Fresh material from Caucasus was collected by pitfall trapping, preserved in $70 \%$ ethanol and studied using a MBS-9 stereo microscope. The epigyne was cleared with a hot $20 \% \mathrm{KOH}$ solution. A Levenhuk C-800 digital camera was utilized for drawing the vulva. Images of multiple focal sections were combined using Helicon Focus image stacking software, version 5.1.

The type specimens are shared between the collections of the ZMMU and the Muséum d'histoire naturelle, Geneva, Switzerland (MHNG). 


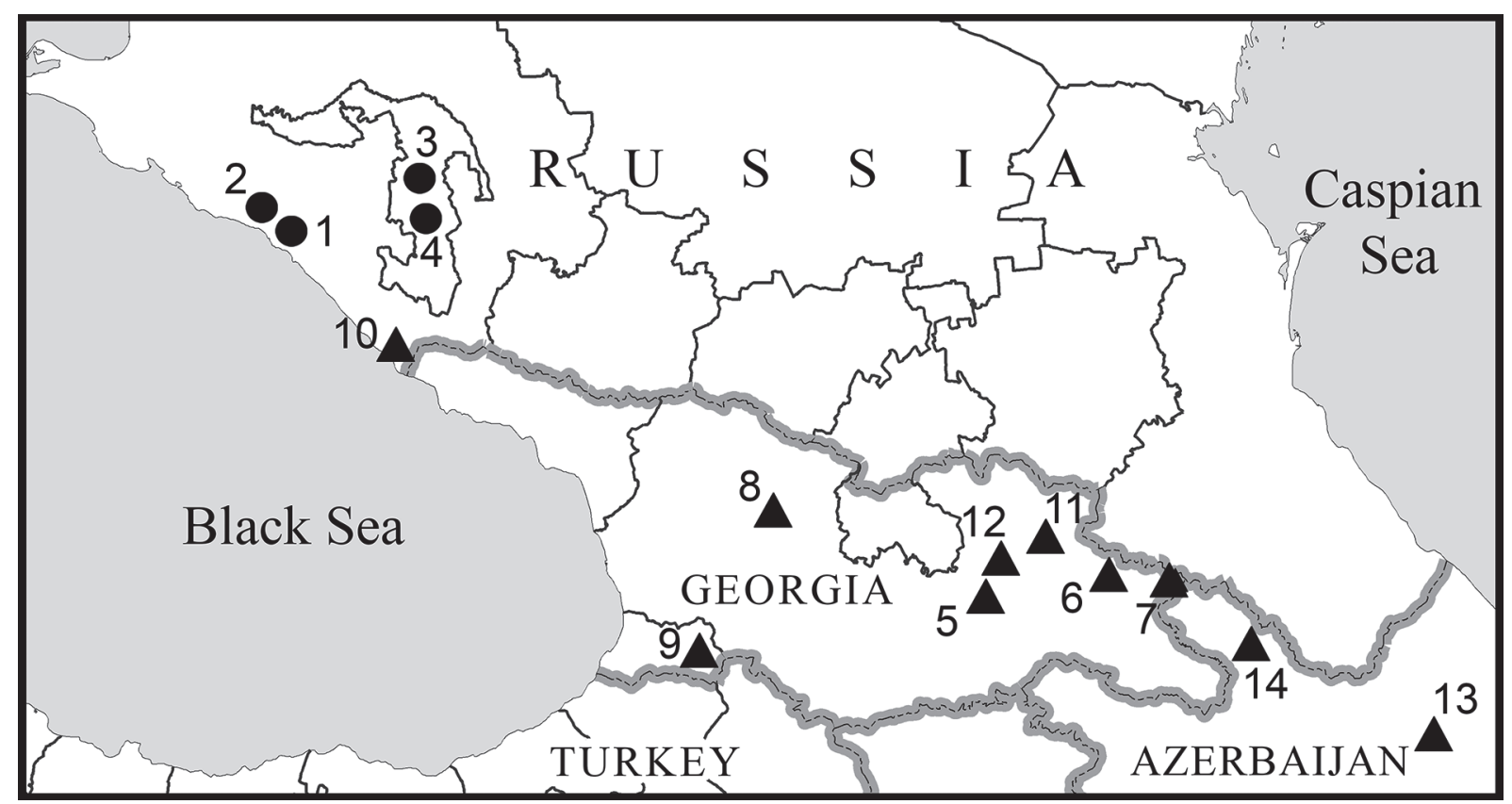

Map. The localities of Bisetifer cephalotus Tanasevitch, 1987 (circle) and B. gruzin sp.n. (triangle): 1 - Psebe; 2 - Defanovka; 3 Maykop; 4 - Polkovnitskaya Balka; 5 - Zedazeni; 6 - Kvareli; 7 - Lagodekhi; 8 - Nikortsminda; 9 - Danisparauli; 10 - Khosta; 11 - Batsara State Reserve; 12 - Magalakhari Pass; 13 - Ismailly; 14 - Bash-Laisky.

Карта. Точки сборов Bisetifer cephalotus Tanasevitch, 1987 (круг) and B. gruzin sp.n. (треугольник): 1 - Псебе; 2 - Дефановка; 3 - Майкоп; 4 - Полковницкая балка; 5 - Зедазени; 6 - Кварели; 7 - Лагодехи; 8 - Никорцминда; 9 - Даниспараули; 10 Хоста; 11 - заповедник Батсара; 12 - перевал Магалахари; 13 - Исмаиллы; 14 - Баш-Лайский.

In the descriptions, the sequence of leg segment measurements is as follows: femur + patella + tibia + metatarsus + tarsus. All measurements are given in $\mathrm{mm}$. Scale lines in the figures correspond to $0.1 \mathrm{~mm}$ unless indicated otherwise.

The chaetotaxy formula means the number of dorsal spines on tibiae I-IV. The terminology of copulatory organs follows that of Merrett [1963], Hormiga [2000] and Tanasevitch [1998, 2015].

The following abbreviations are used in the text and figures: DSA - distal suprategular apophysis; E embolus; Mt - metatarsus; $\mathrm{R}$ - radix; TmI — position of trichobothrium on metatarsus I.

The numbers in square brackets correspond to the numbers of the localities presented on the map.

\section{Taxonomic part}

\section{Bisetifer Tanasevitch, 1987}

Type species: Bisetifer cephalotus Tanasevitch, 1987, by original designation.

DIAGNOSIS. Small-sized Erigoninae, total length 1.18-1.39 mm. Male carapace modified: clypeus slightly prominent conically, head part with a swelling carrying posterior median eyes at base (Figs 1-6). Leg chaetotaxy 2.2.1.1. Metatarsi I-III each with a trichobothrium. TmI 0.40-0.45. Male palp small and compact, palpal tibia with a curved ventro-prolateral outgrowth terminated with a pair of large, strong, distally serrate setae differing in size. Distal suprategular apophysis hypertrophied, hook-shaped, with several apophyses of complicated configuration. Embolus small, short, hookshaped, its base connecting to radix by a transparent, poorly sclerotized tissue. Duct following through a relatively small radix. Epigyne characterized by presence on its posterior side of special outgrowths where channels of seminal ducts open.

COMPOSITION. Two species: Bisetifer cephalotus Tanasevitch, 1987, and B. gruzin sp.n.

TAXONOMIC REMARKS. In the absence of a modern classification of the subfamily Erigoninae, it is difficult to understand the position of the genus. The chaeto-, trichobothriotaxy and, especially, the shape of the hypertrophied distal suprategular apophysis superficially indicate a similarity to taxa from the Savignia genus-group (sensu Merrett [1963]). In contrast, the structure of the embolic division in Bisetifer is quite different. The conformation of the embolic division bears some resemblance to that of many species of the genus Oedothorax Bertkau, 1883 (see Tanasevitch [2015]). However, in Oedothorax, the duct runs directly from the column to the embolus, escaping the main body of the embolic division, termed "convector" (sensu Tanasevitch [1998, 2015]), while in Bisetifer the duct enters the embolus through its main body, this being denominated as "radix".

DISTRIBUTION. Caucasus. The record of $B$. cephalotus in the Crimea [Kovblyuk, 2007] requires confirmation. 


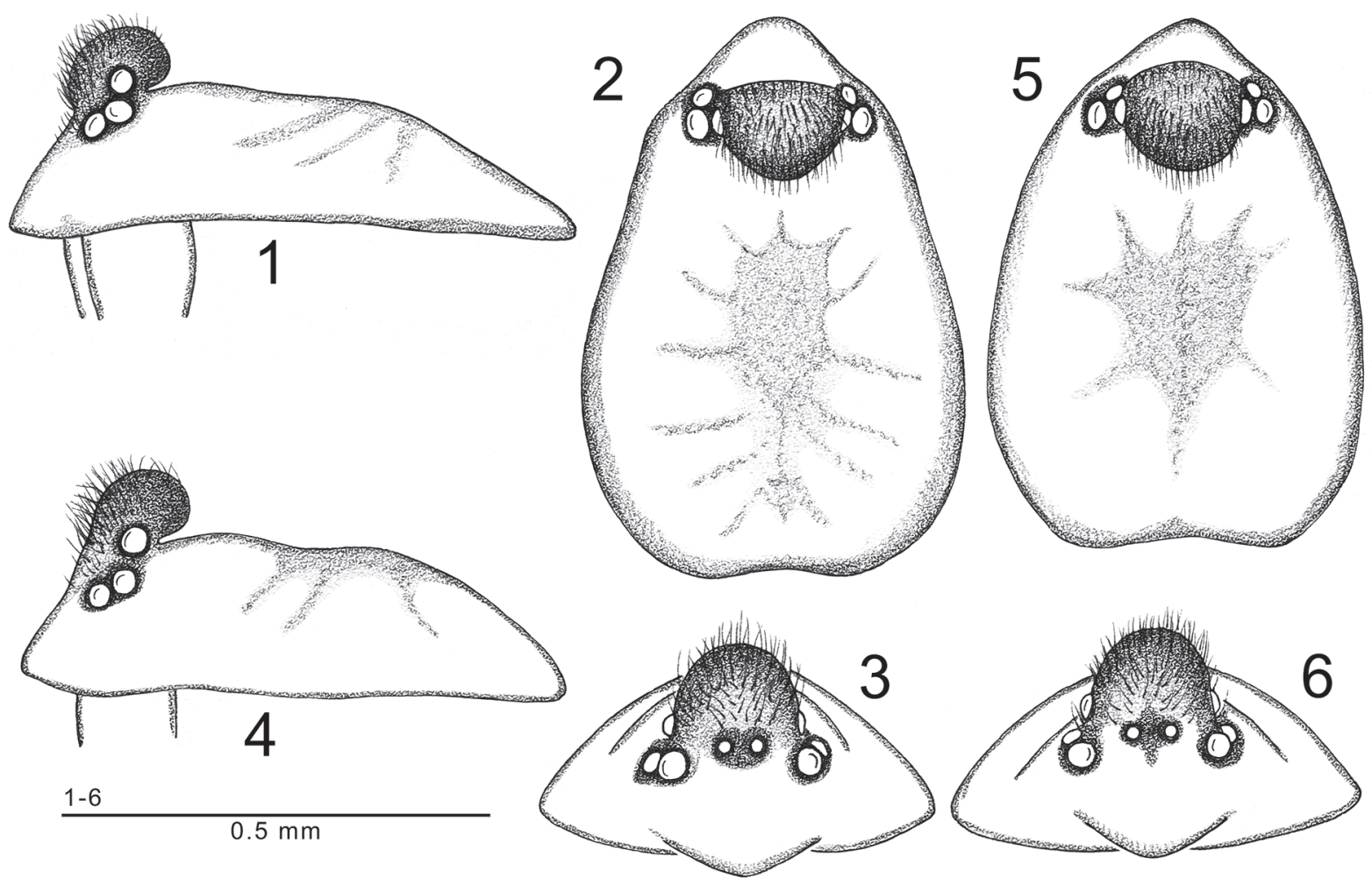

Figs 1-6. Male carapace of Bisetifer cephalotus Tanasevitch, 1987 (1-3), specimen from Polkovnitskaya Balka, and B. gruzin sp.n., specimen from Zedazeni (4-6). 1, 4 - lateral view; 2, 5- dorsal view, 3, 6- frontal view.

Рис. 1-6. Карапакс самца Bisetifer cephalotus Tanasevitch, 1987, экземпляр из Полковницкой балки, (1-3) и B. gruzin sp.n., экземпляр из Зедазени (4-6). 1, 4 - вид сбоку; 2, 5- вид сверху; 3, 6 - вид спереди.

\section{Bisetifer cephalotus Tanasevitch, 1987}

Figs $1-3,7-18$

1987 Bisetifer cephalotus Tanasevitch: 342, figs 81-86, o holotype and $\sigma^{7}$ paratype from Psebe, Krasnodar Province, reexamined.

TYPE MATERIAL EXAMINED: $\sigma^{7}$ holotype of Bisetifer cephalotus (ZMMU, Ta-4471), Caucasus, RUSSIA, Krasnodar Province (= Kray), Tuapse Distr., $15 \mathrm{~km}$ of Novomikhailovsky, Psebe [1], deciduous forest, litter, under stones, 29.X.1981, leg. S. Golovatch; $\sigma^{7}$ paratype of Bisetifer cephalotus (ZMMU, Ta-4471), same locality, together with holotype.

ADDITIONAL MATERIAL EXAMINED: 1 (ZMMU, from CAT, labeled as gen. sp.), Krasnodar Province, Goryachiy Klyuch, Defanovka $\left(44.42524^{\circ} \mathrm{N} 38.77865^{\circ} \mathrm{E}\right)$ [2], Ouercus \& Acer forest, litter, 29.X.1981, leg. S. Golovatch; 2 oO (MHNG), Adygea, Maykop, $300 \mathrm{~m}$ a.s.1., $\left(44.582594^{\circ} \mathrm{N} 40.115125^{\circ} \mathrm{E}\right)$ [3], Ouercus \& Carpinus forest, litter, 6.V.2007; 3 +o (ZMMU), Maykop Distr., 6 $\mathrm{km} \mathrm{S}$ of Pervomayskiy, environs of "Lesnaya skazka", Polkovnitskaya Balka $\left(44.3454^{\circ} \mathrm{N} 40.18947^{\circ} \mathrm{E}\right)$ [4], Quercus \& Carpinus forest, 16.III-1.IV.2011; $23 \sigma^{7} \sigma^{7}$ (ZMMU), 5 ○ $\sigma^{\top}$ (MHNG), same locality, 16.III-15.V.2011; 3 ऊ $\sigma^{7}, 1$ (ZMMU), same locality, 15.IV-2.V.2011; 1 ○ (ZMMU), same locality, 2-15.V.2011; 1 (ZMMU), same locality, 15.V-4.VI.2011; 1 q (ZMMU), same locality, 4-16.VI.2011, all leg. Yu. Chumachenko.

DESCRIPTION. Male, see Tanasevitch [1987], carapace and details of palp structure, see Figs 1-3, 7-16.

Female (specimen from Polkovnitskaya Balka). Total length 1.28. Carapace unmodified, 0.56 long, 0.44 wide, pale brown, with a vague grey radial stripes and a narrow darker margin. Chelicerae 0.24 long. Legs yellow to pale brown. Leg I, 1.14 long $(0.42+0.14+0.35+0.26+$
$0.24)$, IV, 1.50 long $(0.45+0.15+0.38+0.29+0.23)$. Chaetotaxy 2.2.1.1, length of spines about $1-1.5$ diameter of segment. Metatarsi I-IV spineless. Metatarsi IV without trichobothrium. TmI 0.44. Abdomen 0.78 long, 0.59 wide, grey, dorsal pattern absent. Epigyne as in Figs 17 \& 18: posterior side with a pair of nipple-shaped outgrowths where channels of seminal ducts open.

REMARKS. Bisetifer cephalotus was correctly recorded only from a single locality, i.e., Psebe, Krasnodar Province [Tanasevitch, 1987]. All other records from the Caucasus [Tanasevitch, 1987 in part, 1990; Ponomarev, Chumachenko, 2007] appear to be misidentifications and actually refer to $B$. gruzin sp.n., which is described below. The finding of $B$. cephalotus in the Crimea [Kovblyuk, 2007] requires confirmation.

DISTRIBUTION. Caucasus: Krasnodar Province and Adygea, Russia, see Map.

TAXONOMIC REMARKS. See Diagnosis under Bisetifer gruzin sp.n.

\section{Bisetifer gruzin sp.n.}

Figs 4-6, 19-31.

1987 Bisetifer cephalotus Tanasevitch: 342, fig. 87, $0^{7} \sigma^{7}$ in part, 오, re-examined.

1990 B. cephalotus Tanasevitch: $45,0^{7} O^{7} \&$ 우, partly reexamined.

2007 B. cephalotus Ponomarev, Chumachenko: 154, examined. 

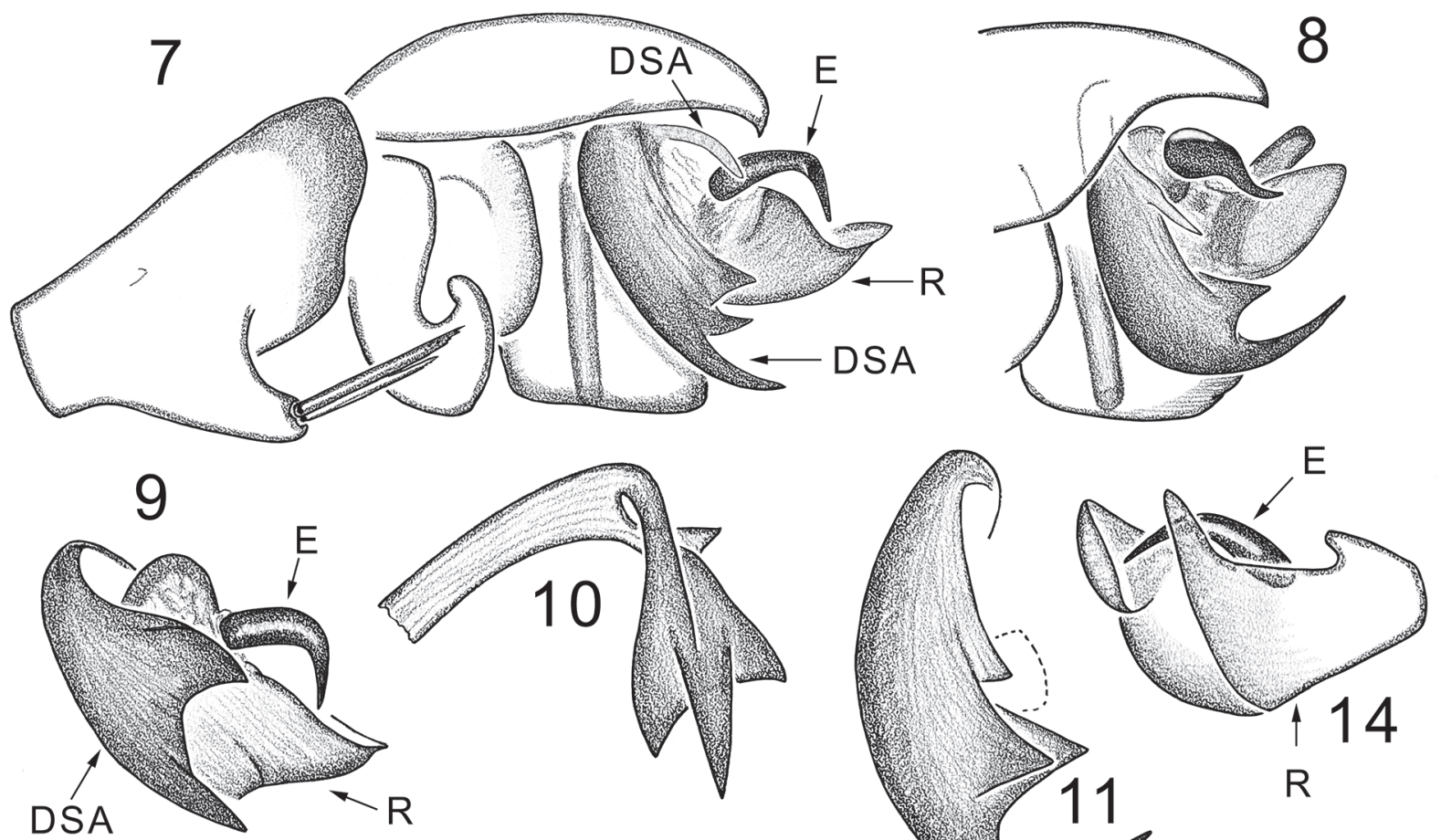

$11-R$
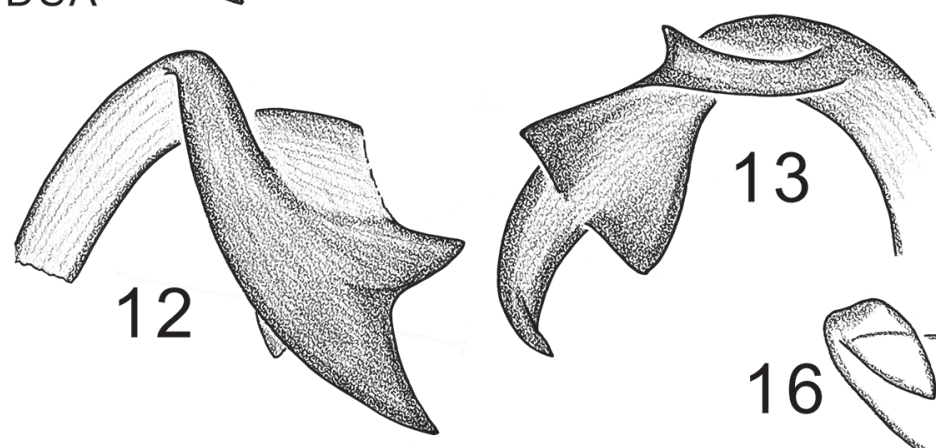

R
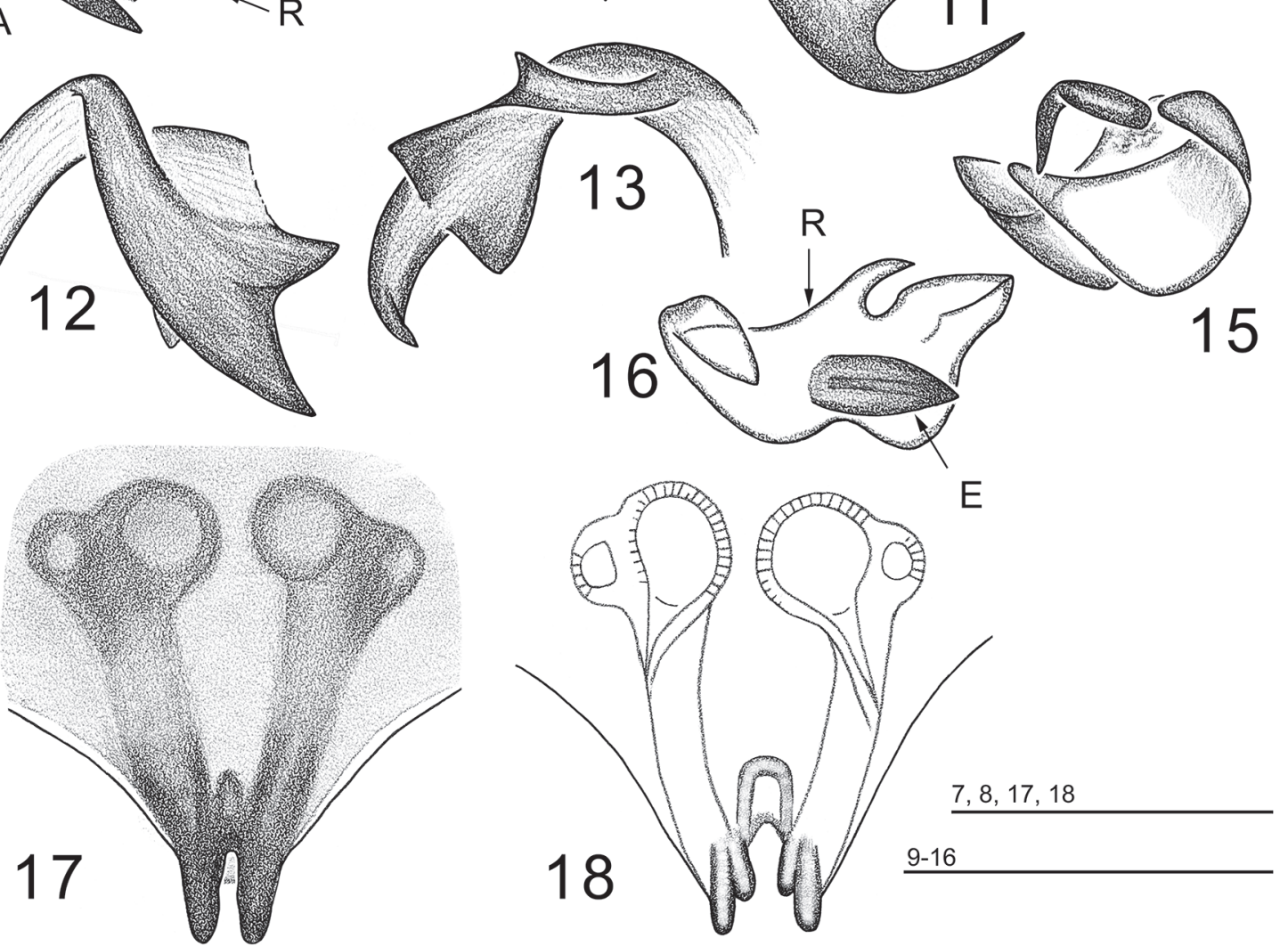

Figs 7-18. Details of male palp structure and epigyne of Bisetifer cephalotus Tanasevitch, 1987, $0^{\top}$ paratype from Psebe, $\bigcirc$ specimen from Polkovnitskaya Balka. 7, 8 - right palp, different aspects; 9 - distal suprategular apophysis and embolic division; 10-13 - distal suprategular apophysis, different aspects; 14-16 - embolic division, different aspects; 17 - epigyne, ventral view; 18 - cleared epigyne, ventral view.

Рис. 7-18. Детали строения пальпы самца и эпигины самки Bisetifer cephalotus Tanasevitch, 1987, паратип O из Псебе, + из Полковницкой балки. 7, 8 - правая пальпа, разные аспекты; 9 - distal suprategular apophysis и эмболюсный отдел; 10-13 - distal suprategular apophysis, разные аспекты; 14-16 — эмболюсный отдел, разные аспекты; 17 — эпигина, вид снизу; 18 — просветлённая эпигина, вид снизу. 

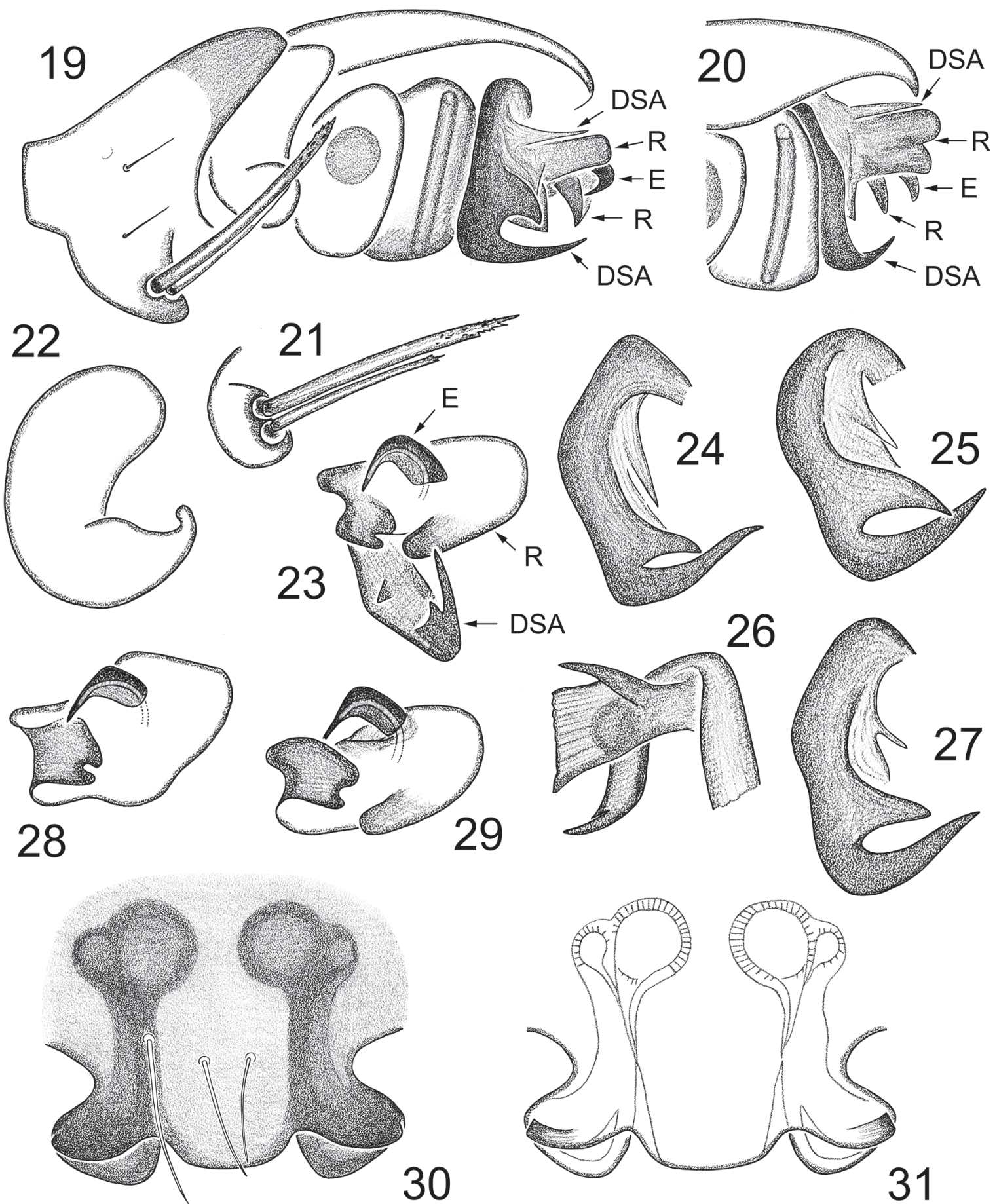

19,20

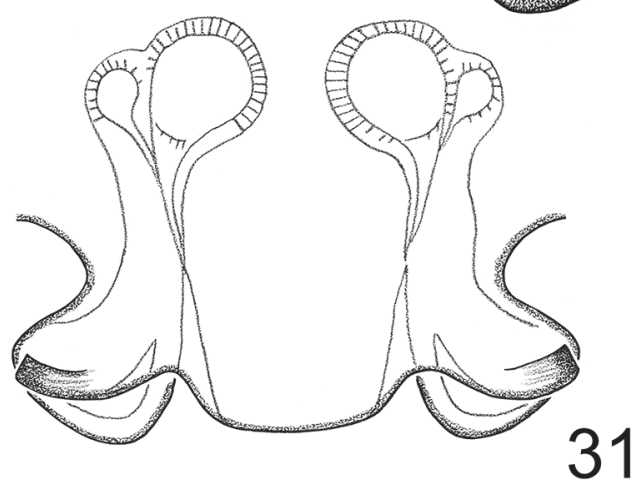

$21-31$

Figs 19-31. Details of male palp structure (19-29) and epigyne (30,31) of Bisetifer gruzin sp.n., $\bigcirc^{\top} \&$ \& specimens from Zedazeni. 19, 20 - right palp, different aspects; 21 - setae at apex of palpal tibial apophysis; 22 - paracymbium; 23 - distal suprategular apophysis and embolic division; 24-27 - distal suprategular apophysis, different aspects; 28,29 - embolic division, different aspects; $30-$ epigyne, ventral view; 31 - cleared epigyne, ventral view.

Рис. 19-31. Детали строения пальпы самца (19-29) и эпигины самки $(30,31)$ Bisetifer gruzin sp.n., экземпляры $0^{7}$ и $\odot$ из Зедазени. 19, 20 - правая пальпа, разные аспекты; 21 - сеты на выросте голени пальпы; 22 парацимбиум; 23 - distal suprategular apophysis и эмболюсный отдел; 24-27 - distal suprategular apophysis, разные аспекты; 28, 29 - эмболюсный отдел, разные аспекты; 30 - эпигина, вид снизу; 31 - просветлённая эпигина, вид снизу. 
NAME. A noun in apposition transliterating the Russian word "gruzin", meaning a native of Georgia, Transcaucasia.

DIAGNOSIS. The new species is very similar to the single congener, Bisetifer cephalotus, but the male differs by certain details of structure of the distal suprategular apophysis (Figs 10-13 cf. Figs 24-27), as well as by the shape of the embolic division (Figs 1416 cf. Figs 28-29); the female can easily be distinguished by the shape of the outgrowths on the posterior side of the epigyne: nipple-shaped in B. cephalotus, versus bow-shaped in the new species (Figs 17 \& $18 \mathrm{cf}$. Figs 30 \& 31).

HOLOTYPE $\sigma^{7}$ (ZMMU, from CAT, labeled as Bisetifer cephalotus), Caucasus, GEORGIA, Saguramo Nature Reserve, NE of Mtskheta, Zedazeni $\left(41.900282^{\circ} \mathrm{N} 44.760311^{\circ} \mathrm{E}\right)$ [5], 1100 $1200 \mathrm{~m}$ a.s.l., Fagus, Carpinus, Acer etc. forest, litter and under bark, 20.V.1987, leg. S. Golovatch \& K. Eskov.

PARATYPES: $10^{7}, 4$ 우 (ZMMU), $10^{\top}, 2$ ㅇ (MHNG), same locality, together with holotype, 20.V.1987, leg. S. Golovatch \& K. Eskov; 2 OP (ZMMU, from CAT, labeled as Bisetifer cephalotus), GEORGIA, N of Kvareli $\left(41.948043^{\circ} \mathrm{N} 45.817127^{\circ} \mathrm{E}\right)$ [6], 700 750 m a.s.1., Fagus, Carpinus, Quercus etc. forest, litter and under bark, 4.V.1987, leg. S. Golovatch \& K. Eskov; 1 ㅇ (ZMMU, paratype Ta-4473 of B. cephalotus), environs of Lagodekhi $\left(41.825222^{\circ} \mathrm{N} 46.281596^{\circ} \mathrm{E}\right)$ [7], Lagodekhi National Park, Fagus, Fraxinus, Acer etc. forest, litter, 600-700 m a.s.1., 5-6.V.1983, leg. S. Golovatch; $1 \mathrm{O}^{7}, 1$ (ZMMU, Ta-4475, paratypes of Bisetifer cephalotus, $)$, Ambrolauri Distr., Nikortsminda $\left(42.462178^{\circ} \mathrm{N}\right.$ $43.090795^{\circ} \mathrm{E}$ ) [8], mixed Abies \& deciduous forest, litter, 24.X.1981, leg. S. Golovatch; 1 + (ZMMU, Ta-4474, paratype of B. cephalotus), Adjara (= Adjaria), Khulo Distr., $3 \mathrm{~km} \mathrm{~W}$ of Danisparauli $\left(41.648027^{\circ} \mathrm{N} 42.462171^{\circ} \mathrm{E}\right)$ [9], deciduous forest, litter, 10.X.1981, leg. S. Golovatch; 1 q (ZMMU), RUSSIA, Krasnodar Province, Sochi, Khosta, Caucasian Nature Reserve, Taxus \& Buxus grove $\left(43.523797^{\circ} \mathrm{N} 39.868919^{\circ} \mathrm{E}\right)$ [10], III-V.2006, leg. Yu. Chumachenko.

UNEXAMINED MATERIAL. The material listed below was reported as Bisetifer cephalotus by Tanasevitch [1990], but has not been found in any collections, possibly lost. Nevertheless, the specimens most probably belong to $B$. gruzin sp.n., because of the well recognizable females: $2 O^{7} O^{7}, 8$ 우, Caucasus, GEORGIA, Batsaro Nature Reserve [11], 500 m a.s.1., Fagus, Quercus \& Carpinus forest, 4.V.1987, leg. S. Golovatch \& K. Eskov; 1 + Pass Magalakhari between Akhmeta and Tianeti [12], $1200 \mathrm{~m}$ a.s.l., Fagus forest, 6.V.1987, leg. S. Golovatch \& K. Eskov; $10^{7}, 2$ 우, AZERBAIJAN, $12 \mathrm{~km}$ E of Ismailly, Girdyman-Chay River Valley [13], 850-880 m a.s.1., Fagus forest, litter, 1.V.1987, leg. S. Golovatch \& K. Eskov; 2 ofo, $30 \mathrm{NW}$ of Sheki, above Bash-Laisky [14], $1250 \mathrm{~m}$ a.s.l., Fagus forest, litter, 1.V.1987, leg. S. Golovatch \& K. Eskov.

DESCRIPTION. Male. Total length 1.38. Carapace 0.65 long, 0.48 wide, reddish-brown, with a narrow darker margin and a vague polygonal grey spot in middle part; modified as in Figs 4-6: head part with a black swelling carrying posterior median eyes at base. Chelicerae 0.21 long. Legs yellow to pale brown. Leg I, 1.57 long $(0.45+0.15+0.38+0.30+0.29)$, IV, 1.58 long $(0.45+0.15+0.44+0.30+0.24)$. Chaetotaxy 2.2.1.1, length of spines about 1-1.5 diameter of segment. Metatarsi I-IV spineless. Metatarsi IV without trichobothrium. TmI 0.43. Palp (Figs 19-29): tibia with a ventro-prolateral outgrowth bearing two thick, strong, distally serrate setae differing in size: one seta slightly shorter and narrower, in some view aspects the larger seta hiding the smaller one. Paracymbium relatively small, simple, L-shaped. Distal suprategular apophysis very large, well-sclerotized, with a compli- cated arrangement of apophyses in its middle part, distally stylet-shaped and orthogonally curved. Embolus small, short, hook-shaped, duct entering embolus through radix. Radix relatively small, its edge bent, with a small hollow apically. Abdomen 0.78 long, 0.51 wide, dark grey, dorsal pattern absent.

Female. Total length 1.35. Carapace unmodified, 0.56 long, 0.45 wide. Chelicerae 0.20 long. Leg I, 1.47 long $(0.47+0.15+0.35+0.27+0.23)$, IV, 1.51 long $(0.45+0.15+0.39+0.29+0.23)$. Chaetotaxy 2.2.1.1, length of spines about 1 diameter of segment. Metatarsi I-IV spineless. Metatarsi IV without trichobothria. TmI 0.44. Abdomen 0.83 long, 0.63 wide, grey, dorsal pattern absent. Epigyne as in Figs 30 \& 31: with a pair of bow-shaped outgrowths on it posterior side, in which channels of the seminal ducts open.

REMARKS. All previous records of B. cephalotus from the Caucasus [Tanasevitch, 1987 in part, 1990; Ponomarev, Chumachenko, 2007], except for Psebe, Krasnodar Province [Tanasevitch, 1987], actually refer to B. gruzin sp.n.

DISTRIBUTION. Caucasus: Krasnodar Province, Russia; Georgia, Azerbaijan, see Map.

ACKNOWLEDGEMENTS. We are very grateful to Kirill Mikhailov (Moscow) for the opportunity to work with the collections of the ZMMU. Special thanks go Sergei Golovatch (Moscow) who kindly checked the English of an advanced draft.

\section{References}

Hormiga G. 2000. Higher level phylogenetics of erigonine spiders (Araneae, Linyphiidae, Erigoninae) // Smithsonian Contributions to Zoology. No.609. P.1-160.

Kovblyuk N.M. 2007. [New data on spiders (Aranei) of the Crimea] // Problemy i perspektivy obshchei entomologii. Tezisy dokladov XIII s'ezda Russkogo entomologicheskogo obshchestva, Krasnodar, 9-15 sentyabrya 2007. Krasnodar: FGOU VPO Kubanskii gosudarstvennyi agrarnyi universitet. P. 152-153 [in Russian].

Merrett P. 1963. The palpus of male spiders of the family Linyphiidae // Proceedings of the Zoological Society of London. Vol.140. P.347-467.

Ponomarev A.V., Chumachenko Yu.A. 2007. [Arachnida in Ground Mesofauna of Yew-box Grove of the Caucasian Biosphere Reserve] // G.G. Matishov (ed.). Studies of the Southern Research Centre of the Russian Academy of Sciences. Issue 3: Biodiversity and Transformation of Mountain Ecosystems of the Caucasus. Rostov-on-Don: SSC RAS Publishing. P.151163 [in Russian].

Tanasevitch A.V. 1987. The linyphiid spiders of the Caucasus, USSR (Arachnida: Araneae: Linyphiidae) // Senckenbergiana biologica. Bd.67. H.4-6. P.297-383.

Tanasevitch A.V. 1990. [The spider family Linyphiidae in the fauna of the Caucasus (Arachnida, Aranei)] // Striganova B.R. (ed.). Fauna of the terrestrial invertebrates of the Caucasus. Moscow: Nauka Publ. P.5-114 [in Russian].

Tanasevitch A.V. 1998. Gorbothorax n. gen., a new linyphiid spider genus from the Nepal Himalayas (Arachnida, Araneae, Linyphiidae) // Bonner Zoologische Beiträge. Bd.47. P.421-428.

Tanasevitch A.V. 2015. Notes on the spider genus Oedothorax Bertkau, 1883 with description of eleven new species from India (Linyphiidae: Erigoninae) // Revue suisse de Zoologie. T.122. Fasc.2. P.381-398.

Responsible editor K.G. Mikhailov 